\title{
POLYMORPHISMS OF INSULIN RECEPTOR SUBSTRATE 1 AS A RISK FACTOR FOR TYPE 2 DIABETES MELLITUS, OBESITY AND CHRONIC PANCREATITIS AMONG POPULATION OF TERNOPIL REGION
}

\author{
U.P. Hevko, M.I. Marushchak \\ I. HORBACHEVSKY TERNOPIL NATIONAL MEDICAL UNIVERSITY, TERNOPIL, UKRAINE
}

Background. The course of type 2 diabetes mellitus (T2DM), obesity and chronic pancreatitis (CP) in most cases is not isolated, so it requires broadening the knowledge about the pathogenetic links at their combined course. Despite significant advances in genome research, most of the genetic factors that cause development of T2DM are still unclear.

Objective. The aim of the study was to establish the prevalence of IRS1 gene polymorphism in the patients with T2DM as well as obesity and CP.

Methods. The study involved 33 patients with T2DM who were hospitalized in the endocrinology department of Ternopil University Hospital in 2019-2020 and 10 apparently healthy patients. Analysis of IRS1 gene polymorphism (SNP in the promoter region - rs2943640; gene localization 2q36.3) was performed on the basis of polymerase chain reaction data using specific primers.

Results. It was found that the frequencies of the genotype responsible for C/A polymorphism of IRS1 gene in T2DM, T2DM with obesity and in the combined course of T2DM with obesity and CP did not deviate significantly from the Hardy-Weinberg equilibrium ( $p>0.05$ ). The patients with combined course of T2DM, obesity and chronic pancreatitis experienced a probable influence of genotypes C/C and C/A of IRS1 gene on the development of the studied comorbidity $(p<0.05)$, which is confirmed by a probable difference in the dominant model of IRS1 gene inheritance only when T2DM was combined with obesity and CP compared to the control group $(p<0.001)$.

Conclusions. The presence of the $C$ allele in both homozygous and heterozygous states may increase the risk of T2DM comorbidity, obesity and CP in the population of Ternopil region.

KEYWORDS: type 2 diabetes mellitus; obesity; chronic pancreatitis; insulin receptor substrate 1; genes polymorphism.

\section{Introduction}

Type 2 diabetes mellitus (T2DM) is a multifactorial genetic disease that causes significant morbidity and mortality worldwide [1]. Multimorbidity, the presence of two or more chronic diseases [2], is typical for patients with T2DM, which makes multimorbidity in this population a significant clinical issue. Nowakowska et al. found out that almost $75 \%$ of patients had at least one additional comorbidity at the time of T2DM diagnosis, and $44 \%$ - at least two comorbidities [3]. Other studies indicate diabetic complications in $90 \%$ [4], 91.4\% [5], 84.6\% [6], $44 \%$ [7] of patients with T2DM, which probably depends on the age and gender coverage of the respondents in the study.

The course of T2DM, obesity and chronic pancreatitis (CP) in most cases is not defined, so it requires broadening the knowledge about the pathogenetic links at their combined course *Corresponding author: Mariya Marushchak, Department of Functional and Laboratory Diagnostics, I. Horbachevsky Ternopil National Medical University, 1 Maidan Voli, 46001 Ternopil, Ukraine.E-mail: marushchak@tdmu.edu.ua
[8-11]. It is obvious that T2DM is a poorly controlled epidemic that requires active research of the mechanisms of development, features of the course, methods of prevention, treatment and prevention of complications [12]. Despite significant advances in genome research, most of the genetic factors that cause development of T2DM are still unclear $[13,14]$. The insulin receptor substrate (IRS) is a key central receptor in transmission of insulin signals. Several IRS polymorphisms have been identified, but the Gly to Arg 972 substitution of IRS1 probably is pathogenetically crucial in the development of T2DM [15].

Therefore, the aim of our study was to establish the prevalence of IRS1 gene polymorphism in the patients with type 2 diabetes mellitus as well as obesity and chronic pancreatitis.

\section{Methods}

The study involved 33 patients with T2DM who were hospitalized in the endocrinology 
department of Ternopil University Hospital in 2019-2020 and 10 apparently healthy patients. The distribution of groups is presented in Table 1.

There was no significant difference in age and gender between the patients of experimental groups. All patients were informed of the purpose of the clinical trial and gave written informed consent to participate in it. The privacy of the patient's identity and health has been maintained.

Verification of T2DM was performed in accordance with the recommendations of the American Diabetes Association (2019) [16]. The criteria for T2DM diagnosing were based on the rate of glycated hemoglobin (HbA1c) $(\geq 6.5 \%)$, which was determined using the COBAS 6000 automatic biochemical analyzer (Roche Hitachi, Germany).

Verification of chronic pancreatitis (CP) was based on the Unified Clinical Protocol of Primary, Secondary (Specialized) Medical Care and Medical Rehabilitation "Chronic Pancreatitis" and the recommendations of the American Pancreatic Association $[15,16]$.

BMI was calculated by the BMI formula = body weight $(\mathrm{kg}) /$ height $\left(\mathrm{m}^{2}\right)$. The data were interpreted according to the WHO recommendations: normal weight in the range of 20.0 $24.9 \mathrm{~kg} / \mathrm{m}^{2}$; overweight (pre-obesity) - 25.0$29.9 \mathrm{~kg} / \mathrm{m}^{2}$; class 1 obesity - 30.0-34.9 kg/m; class 2 obesity - 35.0-39.9 kg/m² and class 3 obesity $>40 \mathrm{~kg} / \mathrm{m}^{2}$ [17].

Inclusion criteria were: clinical, laboratory and instrumental signs of T2DM, CP and obesity, no severe increase (not more than in 3 times from the upper of norm maximum) of alpha-amylase, lipase, ALT, AST, alkaline phosphatase, gamma-glutamyltranspeptidase in the blood.

Exclusion criteria from the study were: signs of clinically significant neurological, mental, renal, hepatic, immunological, gastrointestinal, urogenital disorders, musculoskeletal lesions, skin, sense organs, endocrine (except T2DM) or hematological diseases that were uncontrolled, acute pancreatitis, unstable or life- threatening heart diseases, malignant neoplasms not in complete remission for at least 5 years, medication (drug) dependence, alcohol dependence.

Analysis of IRS1 gene polymorphism (SNP in the promoter region - rs2943640; gene localization - 2q36.3) was performed on the basis of polymerase chain reaction data using specific primers. Genomic DNA was extracted from peripheral blood leukocytes using a commercially available DNA isolation kit (QIAamp Blood DNA Mini Kit, QIAGEN, Germany). The rs2943640 IRS1 gene polymorphism was genotyped using the TaqMan real-time PCR method (Applied Biosystems, Foster City, CA, USA). Three genotypes of IRS1 polymorphism (rs2943640) were defined (C/C, C/A and $A / A)$.

Statistical analysis of the data was performed using the STATISTICA 7.0 software. The HardyWeinberg equilibrium was used to verify the conformity of the genotypes of the selected samples to the general population. Comparison of the frequencies observed and expected, calculated according to the formula p2 $+2 p q+$ q2 = 1 (the Hardy-Weinberg equilibrium), was performed using the Pearson's chi-square $\chi^{2}$. In assessment of the reliability coefficient $p>0.05$, the null hypothesis of the samples equality was taken into the account, i.e. the correspondence of the selected sample to the general population.

Comparative analysis of frequency tables was performed using the Pearson's chi-square $\chi^{2}$ and two-tailed $p$-value for Fisher's exact test (in cases of the expected frequencies of individual indicators not exceeding 5).

To evaluate the influence of the factor (the presence of a certain genotype or allele of the gene) on the disease incidence, calculation of the odds ratio (OR), its 95\% confidence interval (CI) and the reliability coefficient $p$-value was used.

\section{Results}

Insulin receptor substrate (IRS) molecules are key mediators in transmission of insulin signals. Several polymorphisms have been defined in IRS genes, but only the Gly to Arg

Table 1. Characteristic features of the study groups $(n=44)$

\begin{tabular}{|c|l|c|c|}
\hline Group № & \multicolumn{1}{|c|}{ Characteristics of the group } & $\mathrm{n}$ & $\%$ \\
\hline 1 & T2DM patients with normal body weight without chronic pancreatitis & 9 & 22.7 \\
\hline 2 & T2DM patients with overweight / obesity without chronic pancreatitis & 14 & 31.9 \\
\hline 3 & $\begin{array}{l}\text { T2DM patients with overweight / obesity with concomitant chronic } \\
\text { pancreatitis }\end{array}$ & 10 & 22.7 \\
\hline 4 & Apparently healthy patients (control) & 10 & 22.7 \\
\hline
\end{tabular}


972 substitution of IRS-1 is pathogenically crucial in development of T2DM. However, other polymorphisms described in IRS-1 gene are associated with insulin resistance (IR) in T2DM. The frequency distribution of polymorphic genotypes of IRS1 gene (rs2943640) and verification of conformity with the HardyWeinberg population equilibrium were performed in the experimental and control groups. It was found out that the frequencies of the genotype responsible for C/A polymorphism of IRS1 gene in T2DM, T2DM with obesity and at the combined course of T2DM with obesity and CP did not deviate significantly from the HardyWeinberg equilibrium ( $p>0.05)$, while in the control group the selected sample did not correspond to the general population (Table 2).

The corresponding frequencies for the genotypes of IRS1 gene were as follows: $66.7 \%$ for $C / A$ and $33.3 \%$ for $A / A$ in the experimental group $1 ; 21.4 \%$ for $C / A, 64.3 \%$ for $C / A$ and $14.3 \%$ for $A / A$ in the group $2 ; 70.0 \%$ for $C / A, 10.0 \%$ for C/A and $20.0 \%$ for $A / A$ in the group 3 and $100.0 \%$ for C/A in the control group (Table 3).

The frequencies of alleles of IRS1 gene in the patients involved in the study are presented in Table 2. In the patients with T2DM the allele $C$ predominated, in the patients with T2DM + obesity $+C P$ - allele $A$, while in the patients with T2DM + obesity and in the control group, the $C$ allele and the $A$ allele were almost equal.

The obtained results, presented in Table 4, indicate the absence of a statistically significant relationship between the factor (presence of alleles $C$ or $A$ ) and the disease incidence $(p>0.05)$.

Evaluation of the reliability coefficient in the analysis of odds ratio showed probable influence of the genotypes $C / C$ and $C / A$ of the IRS1 gene on development of T2DM combined with

Table 2. Polymorphism of IRS1 genes (rs2943640) according to the Hardy-Weinberg equilibrium in T2DM and its comorbidity

\begin{tabular}{|c|c|c|c|c|c|c|c|c|c|}
\hline \multirow{2}{*}{\multicolumn{2}{|c|}{ Genotypes }} & \multicolumn{2}{|c|}{$\begin{array}{c}\text { T2DM } \\
\text { (Group 1) }\end{array}$} & \multicolumn{2}{|c|}{$\begin{array}{l}\text { T2DM+obesity } \\
\text { (Group 2) }\end{array}$} & \multicolumn{2}{|c|}{$\begin{array}{l}\text { T2DM+obesity+CP } \\
\text { (Group 3) }\end{array}$} & \multicolumn{2}{|c|}{ Control } \\
\hline & & Expected & Present & Expected & Present & Expected & Present & Expected & Present \\
\hline \multicolumn{10}{|c|}{ Polymorphism of IRS1 gene (rs2943640) } \\
\hline $\begin{array}{l}\text { Homozygotes } \\
\text { that are common }\end{array}$ & $\mathrm{C} / \mathrm{C}$ & 1 & 0 & 4,0 & 3 & 6.4 & 7 & 2.5 & 0 \\
\hline Heterozygotes & $\mathrm{C} / \mathrm{A}$ & 4 & 6 & 7.0 & 9 & 3.2 & 1 & 5 & 10 \\
\hline $\begin{array}{l}\text { Homozygotes } \\
\text { that are rare }\end{array}$ & $\mathrm{A} / \mathrm{A}$ & 4 & 3 & 3.0 & 2 & 0.4 & 2 & 2.5 & 0 \\
\hline$\chi^{2}, p$ & & \multicolumn{2}{|c|}{$\chi^{2}=2.25 ; p>0.05$} & \multicolumn{2}{|c|}{$\chi^{2}=1.20 ; p>0.05$} & \multicolumn{2}{|c|}{$\chi^{2}=2.45 ; p>0.05$} & \multicolumn{2}{|c|}{$\chi^{2}=10.00 ; p<0.01$ * } \\
\hline
\end{tabular}

Table 3. Frequency of the alleles of the IRS1 genes ( $r$ 2943640) in T2DM and its comorbidity

\begin{tabular}{|l|c|c|c|c|c|c|c|c|}
\hline \multirow{2}{*}{ Frequency of alleles } & $\begin{array}{c}\text { T2DM } \\
\text { (group 1) }\end{array}$ & $\begin{array}{c}\text { T2DM+obesity } \\
\text { (group 2) }\end{array}$ & $\begin{array}{c}\text { T2DM+obesity+CP } \\
\text { (group 3) }\end{array}$ & \multicolumn{3}{c|}{ Control } \\
\cline { 2 - 8 } & $\mathrm{n}$ & $\%$ & $\mathrm{n}$ & $\%$ & $\mathrm{n}$ & $\%$ & $\mathrm{n}$ & $\%$ \\
\hline Polymorphism of IRS1 gene (rs2943640) \\
\hline Allele C
\end{tabular}

Table 4. The odds ratio for alleles in different study groups in T2DM and its comorbidity

\begin{tabular}{|l|c|c|c|c|c|c|}
\hline \multirow{2}{*}{ Group } & \multicolumn{5}{|c|}{ IRS1 gene (rs2943640) } \\
\cline { 2 - 7 } & \multicolumn{3}{|c|}{ Allele C } & Allele A & $\mathrm{p}$ \\
\cline { 2 - 7 } & OR & $95 \%$ CI & $p$ & 2.00 & $0.54-7.45$ & $>0.05$ \\
\hline $\begin{array}{l}\text { T2DM } \\
\text { (Group 1) }\end{array}$ & 0.50 & $0.13-1.86$ & $>0.05$ & 0.87 & $0.27-2.73$ & $>0.05$ \\
\hline $\begin{array}{l}\text { T2DM+obesity } \\
\text { (Group 2) }\end{array}$ & 1.15 & $0.37-3.64$ & $>0.05$ & 0.25 & $0.06-1.02$ & $>0.05$ \\
\hline $\begin{array}{l}\text { T2DM+obesity+CP } \\
\text { (Group 3) }\end{array}$ & 4.00 & $0.98-16.27$ & $>0.05$ & & & \\
\hline
\end{tabular}


obesity and CP $(p<0.05)$ (Table 5). This is confirmed by a probable difference in the dominant model of IRS1 gene inheritance only in the group with combination of T2DM as well as obesity and CP compared with the control group (reliability coefficient for the chi-square $p<0.001)$. Thus, the presence of the $C$ allele in both homozygous and heterozygous states may increase the risk of T2DM comorbidity, obesity and CP (Table 6).

It should be noted that in recessive models of IRS1 gene inheritance in T2DM, T2DM + obesity and T2DM + obesity + CP no significant differences were established compared with the control group, but there was also a tendency to increase in the probability of development of these diseases in the presence of $C$ allele (Table 7).

\section{Discussion}

It is established that genes are crucial in development of T2DM. Researchers have suggested the interaction between many genetic factors and environmental factors that

Table 5. The odds ratio for genotypes in different study groups in T2DM and its comorbidity

\begin{tabular}{|l|c|c|c|c|c|c|}
\hline \multirow{3}{*}{ Group } & \multicolumn{6}{|c|}{ Genotype } \\
\cline { 2 - 7 } & \multicolumn{6}{|c|}{ Polymorphism of IRS1 gene (rs2943640) } \\
\cline { 2 - 7 } & \multicolumn{2}{|c|}{ CC } & \multicolumn{2}{c|}{ CA } & \multicolumn{2}{c|}{ AA } \\
\cline { 2 - 7 } & OR & $95 \%$ CI & OR & $95 \%$ CI & OR & $95 \%$ CI \\
\hline $\begin{array}{l}\text { T2DM } \\
\text { (Group 1) }\end{array}$ & 1.11 & $0.02-61.38$ & 0.09 & $0.01-2.00$ & 11.31 & $0.50-256.21$ \\
\hline $\begin{array}{l}\text { T2DM+obesity } \\
\text { (Group 2) }\end{array}$ & 6.39 & $0.29-138.94$ & 1.73 & $0.03-99.96$ & 4.20 & $0.18-97.55$ \\
\hline $\begin{array}{l}\text { T2DM+obesity+CP } \\
\text { (Group 3) }\end{array}$ & $71.40 *$ & $3.00-1696.84$ & $0.002 *$ & $0.001-0.13$ & 6.18 & $0.26-146.79$ \\
\hline
\end{tabular}

Note. * $-p<0.05$.

Table 6. Dominant model of IRS1 gene inheritance ( $r$ 2943640) in T2DM and its comorbidity

\begin{tabular}{|c|c|c|c|c|c|c|}
\hline \multirow{2}{*}{ Genotypes } & Experimental group & Control & \multirow[b]{2}{*}{$p_{F}$} & \multirow{2}{*}{ OR } & \multirow{2}{*}{$95 \% \mathrm{CI}$} & \multirow{2}{*}{$\mathrm{p}$} \\
\hline & $\%$ & $\%$ & & & & \\
\hline \multicolumn{7}{|c|}{ T2DM (Group 1) } \\
\hline $\mathrm{C} / \mathrm{C}$ & 0 & 0 & \multirow[t]{2}{*}{-} & 1.11 & $0.02-61.38$ & $>0.05$ \\
\hline$C / A+A / A$ & 100.00 & 100.00 & & 0.90 & $0.02-50.25$ & $>0.05$ \\
\hline \multicolumn{7}{|c|}{ T2DM+obesity (Group 2) } \\
\hline $\mathrm{C} / \mathrm{C}$ & 21.43 & 0 & \multirow[t]{2}{*}{0.239} & 6.39 & $0.29-138.94$ & $>0.05$ \\
\hline$C / A+A / A$ & 78.57 & 100.00 & & 0.16 & $0.01-3.40$ & $>0.05$ \\
\hline \multicolumn{7}{|c|}{ T2DM+obesity+CP (Group 3) } \\
\hline $\mathrm{C} / \mathrm{C}$ & 80.00 & 0 & \multirow[t]{2}{*}{$<0.001 *$} & 71.40 & $3.00-1696.84$ & $0.008 *$ \\
\hline$C / A+A / A$ & 20.00 & 100.00 & & 0.01 & $0.001-0.33$ & $0.008 *$ \\
\hline
\end{tabular}

Note. * - statistically significant results.

Table 7. Recessive model of IRS1 inheritance ( $r$ 2943640) in T2DM and its comorbidity

\begin{tabular}{|c|c|c|c|c|c|c|}
\hline \multirow{2}{*}{ Genotypes } & Experimental group & Control & \multirow{2}{*}{$\mathrm{p}_{\mathrm{F}}$} & \multirow{2}{*}{ OR } & \multirow{2}{*}{$95 \%$ CI } & \multirow{2}{*}{$\mathrm{p}$} \\
\hline & $\%$ & $\%$ & & & & \\
\hline \multicolumn{7}{|c|}{ T2DM (Group 1) } \\
\hline$C / C+C / A$ & 66.67 & 100.00 & \multirow[t]{2}{*}{0.087} & 0.09 & $0.01-2.00$ & $>0.05$ \\
\hline $\mathrm{A} / \mathrm{A}$ & 33.33 & 0 & & 11.31 & $0.50-256.21$ & $>0.05$ \\
\hline \multicolumn{7}{|c|}{ T2DM+obesity (Group 2) } \\
\hline $\mathrm{C} / \mathrm{C}+\mathrm{C} / \mathrm{A}$ & 85.71 & 100.00 & \multirow[t]{2}{*}{0.493} & 0.24 & $0.01-5.53$ & $>0.05$ \\
\hline $\mathrm{A} / \mathrm{A}$ & 14.29 & 0 & & 6.18 & $0.26-146.79$ & $>0.05$ \\
\hline \multicolumn{7}{|c|}{ T2DM+obesity+CP (Group 3) } \\
\hline $\mathrm{C} / \mathrm{C}+\mathrm{C} / \mathrm{A}$ & 80.00 & 100.00 & \multirow[t]{2}{*}{0.474} & 0.16 & $0.01-3.85$ & $>0.05$ \\
\hline $\mathrm{A} / \mathrm{A}$ & 20.00 & 0 & & 6.18 & $0.26-146.79$ & $>0.05$ \\
\hline
\end{tabular}


contribute to the disease development [20]. However, there are only isolated data in the literature on the role of IRS1 polymorphism ( rs2943640) in increased susceptibility to T2DM. Thus, Langenberg $C$ et al. presented the results of the InterAct study, which proved the effect of $C$ allele of IRS1 gene polymorphism (rs2943640) on the risk of T2DM development [21]. In the study prepared by Liu J and et al. 8 SNPs associated with T2DM were found, including rs2943640 variant of IRS1 gene, which was also associated with body mass index [22].

A study of the physical activity genetics made by Loos RJ et al., which included IRS1 ( $r$ 2943640) among the studied genes, showed an increased interaction of the gene with the risk of diabetes, in particular, a dependence on genetic susceptibility to insulin resistance [23]. Another interesting result of this study is the established data on the higher genetic risk of T2DM in individuals with the highest level of physical activity that is consistent with the large-scale study of Langenberg et al. (24), in which the predicted effect of T2DM genetic risk was the strongest among young, lean, and physically active individuals [21]. It should be noted that according to Karaderi T. et al., rs2943640 variant of IRS1 gene is associated with decreased BMI [24]. Our results prove the effect of C allele of IRS1 gene (rs2943640) on the increased susceptibility to the combination of T2DM+obesity+CP, but there is no probable effect of the factor (alleles $C$ and $A$ ) on development of only T2DM and T2DM+obesity. There are no data in the literature on the role of IRS1 gene (variant rs2943640) in increased susceptibility to CP.

There are some limitations in this study that need to be considered when interpreting its results: the sample size is too small, so it is difficult to find significant relationships between the data; inclusion into the experimental groups only of patients with comorbidity T2DM+obesity and T2DM+obesity+CP; patients were not randomly selected generating a potential selection bias. Therefore, we cannot exclude the hypothesis that the evaluated patients do not represent the whole population of the patients with comorbid T2DM, but these results are the first step in finding genes for increased susceptibility to the studied pathology, they reflect a more heterogeneous realworld population characteristic in clinical practice.

\section{Conclusions}

The patients with combined course of T2DM, obesity and chronic pancreatitis have a probable influence of genotypes $\mathrm{C} / \mathrm{C}$ and $\mathrm{C} / \mathrm{A}$ of IRS1 gene on development of the studied comorbidity $(p<0.05)$ that is confirmed by a probable difference in the dominant model of IRS1 gene inheritance only when T2DM is combined with obesity and CP compare to the control group $(p<0.001)$. Thus, the presence of the $C$ allele in both homozygous and heterozygous states may increase the risk of T2DM comorbidity, obesity and CP in the population of Ternopil region.

\section{Funding}

This research received no external funding.

\section{Conflict of Interest}

The authors declare no conflict of interest.

\section{Author Contributions}

Hevko U.P. - methodology, software, validation, formal analysis, investigation, resources, data curation, visualization, writing - original draft, writing - reviewing and editing.

Marushchak M.I. - conceptualization, visualization, supervision, writing - reviewing and editing.

\section{ПОЛІМОРФІЗМ СУБСТРАТУ ІНСУЛІНОВИХ РЕЦЕПТОРІВ 1 ТИПУ ЯК ФАКТОР РИЗИКУ РОЗВИТКУ ЦУКРОВОГО ДІАБЕТУ 2 ТИПУ, ПОЄДНАНОГО 3 ОЖИРІННЯМ ТА ХРОНІЧНИМ ПАНКРЕАТИТОМ У НАСЕЛЕННЯ ТЕРНОПІЛЬСЬКОЇ ОБЛАСТІ}

У.П. Гевко, М.I. Марущак ТЕРНОПІЛЬСЬКИЙ НАЦІОНАЛЬНИЙ МЕДИЧНИЙ УНІВЕРСИТЕТ ІМЕНІ І.Я. ГОРБАЧЕВСЬКОГО МОЗ УКРАЇНИ, ТЕРНОПІЛЬ, УКРАЇНА

Вступ. Перебіг цукрового діабету 2 mипу (T2DM), ожиріння та хронічного панкреатиту (CP) в більшості випадків не є ізольованим, тому потребує поглиблення знань стосовно патогенетичних 
ланок при їх поєднаному перебігу. Незважаючи на значні успіхи у дослідженнях геному, більшість генетичних факторів, що спричинюють розвиток T2DM, залишаються невизначеними.

Мета дослідження - встановити поширення поліморфізму гена субстрату інсулінових рецепторів 1 muny (IRS1) у хворих на T2DM у поєднанні з ожирінням та CP.

Методи дослідження. У дослідження було включено 33 хворих на T2DM, які перебували на стаціонарному лікуванні в ендокринологічному відділенні Тернопільської університетської лікарні у 2019-2020 рр. та 10 практично здорових осіб. Аналіз поліморфізму гена IRS1 (SNP у промоторному регіоні - rs2943640; генна локалізація 2q36.3) проведено на підставі даних полімерної ланцюгової реакції з використанням специфічних праймерів.

Результати. Встановлено, що частоти генотипу, що відповідає за C/A поліморфізм гена IRS1 npu T2DM, T2DM з жжирінням та при поєднаному перебігу T2DM з ожирінням та CP суттєво не відхилялися від рівноваги Харді-Вайнберга (p>0,05). Ухворих на поєднаний перебіг цукрового діабету 2 типу, ожиріння тахронічного панкреатиту виявляється вірогідний вплив генотипів C/C ma C/A гена IRS1 на розвиток досліджуваної коморбідності (p<0,05), що підтверджується вірогідною відмінністю у домінантній моделі успадкування IRS1 гену тільки при поєднанні T2DM з ожирінням та CP порівняно з групою контролю $(p<0,001)$.

Висновки. Наявність алелі С як в гомозиготному, так і в гетерозиготному станах може підвищувати ризик виникнення коморбідності T2DM, ожиріння та CP.

КЛЮЧОВІ СЛОВА: цукровий діабет 2 типу; ожиріння; хронічний панкреатит; субстрат інсулінових рецепторів 1 типу; поліморфізм гена.

\section{Information about the authors}

Hevko U.P. - PhD student, Department of Functional and Laboratory Diagnostics, I. Horbachevsky Ternopil National Medical University, Ternopil, Ukraine.

ORCID 0000-0001-5265-2842, e-mail: gevkoup@tdmu.edu.ua

Marushchak M.I. - professor, Department of Functional and Laboratory Diagnostics, I. Horbachevsky Ternopil National Medical University, Ternopil, Ukraine.

ORCID 0000-0001-6754-0026, e-mail: marushchak@tdmu.edu.ua

\section{References}

1. Roy S, Sherman A, Monari-Sparks MG, Schweiker O, Jain N, Etty Sims E, et al. Association of comorbid and metabolic factors with optimal control of type 2 diabetes mellitus. N Am J Med Sci. 2016; $8(1): 31-9$.

DOI: https://doi.org/10.4103/1947-2714.175197

2. Jani BD, Hanlon P, Nicholl BI, McQueenie R, Gallacher KI, Lee $D$, et al. Relationship between multimorbidity, demographic factors and mortality: findings from the UK Biobank. BMC Med. 2019; 17(1):74.

DOI: https://doi.org/10.1186/s12916-019-1305-X

3. Nowakowska M, Zghebi SS, Ashcroft DM, Buchan I, Chew-Graham C, Holt T, et al.The comorbidity burden of type 2 diabetes mellitus: patterns, clusters and predictions from a large English primary care cohort. BMC Medicine. 2019;17:145.

DOI: https://doi.org/10.1186/s12916-019-1373-y

4. Teljeur C, Smith SM, Paul G, Kelly A, O'Dowd T. Multimorbidity in a cohort of patients with type 2 diabetes. Eur J Gen Pract. 2013;19 (1):17-22.

DOI: https://doi.org/10.3109/13814788.2012.71 4768
5. Lonso-Morán E, Orueta JF, Esteban JIF. The prevalence of diabetes-related complications and multimorbidity in the population with type 2 diabetes mellitus in the Basque Country. BMC Public Health. 2014;14: 1059.

DOI: https://doi.org/10.1186/1471-2458-14-1059

6. Luijks H, Schermer T, Bor H, Weel C, LagroJanssen $T$, Biermans $M$, et al. Prevalence and incidence density rates of chronic comorbidity in type 2 diabetes patients: an exploratory cohort study BMC Med. 2012; 10 (1): 128.

DOI: https://doi.org/10.1186/1741-7015-10-128

7. Struijs JN, Baan CA, Schellevis FG, Westert GP, van den Bos GA. Comorbidity in patients with diabetes mellitus: impact on medical health care utilization. BMC Health Serv Res. 2006; 6: 84.

DOI: https://doi.org/10.1186/1472-6963-6-84

8. Li X, Guo X, Ji H, Niu J, Gao P. Relationships between metabolic comorbidities and occurrence, severity, and outcomes in patients with acute pancreatitis: A narrative review. Biomed Res Int. 2019 Oct 7;2019:2645926.

DOI: https://doi.org/10.1155/2019/2645926 
9. Samsonova NG, Zvenigorod LA. Pancreas and metabolic syndrome. Experimental and clinical gastroenterology. 2011; 11: 68-72.

10. American Diabetes Association. 4. Comprehensive medical evaluation and assessment of comorbidities: Standards of Medical Care in Diabetes-2019. Diabetes care. 2019 Jan 1;42(Supplement 1):S34-45.

DOI: https://doi.org/10.2337/dc19-S004

11. Antonyshyn IV, MI Marushchak, OV Denefil. [State of lipid peroxidation in experimental dietinduced alimentary obesity]. Medical Chemistry. 2014; 16 (3): 61-5. (In Ukrainian)

12. Hevko U, Kozak K, Krynytska I, Marushchak M. Diagnostic value of a complete blood count in type 2 diabetes mellitus and comorbidities. Balkan Medical Union. 2020; 55(4): 601-7. 55.4.06

DOI: https://doi.org/10.31688/ABMU.2020.

13. Plengvidhya N, Chanprasert C, Chongjaroen $N$, et al. Impact of KCNQ1, CDKN2A/2B, CDKAL1, HHEX, MTNR1B, SLC30A8, TCF7L2, and UBE2E2 on risk of developing type 2 diabetes in Thai population. BMC Med Genet. 2018; 19:93.

DOI: https://doi.org/10.1186/s12881-018-0614-9

14. Musiienko VA, Marushchak MI. [Type 2 diabetes and thyroid disease: finding common mechanisms]. Vìsn. med. bìol. dosl.. 2020; 1: 74-82. (In Ukrainian).

DOI: https://doi.org/10.11603/bmbr.2706-6290. 2020.1.11006

15. Yousef AA, Behiry EG, Allah WMA, Hussien AM, Abdelmoneam AA, Imam MH, Hikal DM. IRS-1 genetic polymorphism (r.2963G >A) in type 2 diabetes mellitus patients associated with insulin resistance. Appl Clin Genet. 2018 Sep 28;11:99-106.

DOI: https://doi.org/10.2147/TACG.S171096

16. American Diabetes Association. Cardiovascular disease and risk management: Standards of Medical Care in Diabetes-2019. Diabetes care. 2019 Jan 1;42(Supplement 1):S103-23.

DOI: https://doi.org/10.2337/dc19-S010
17. Conwell DL, Lee LS, Yadav D, Longnecker DS, Miller FH, Mortele KJ, et al. American Pancreatic Association Practice Guidelines in Chronic Pancreatitis: evidence-based report on diagnostic guidelines. Pancreas. 2014;43(8):1143-62.

DOI: https://doi.org/10.1097/MPA. 0000000000000237

18. Order of the Ministry of Health of Ukraine № 638 dated 10.09.2014 https://zakononline.com.ua/ documents/show/35092_35092.

19. Body Mass Index: Considerations for Practitioners / https://www.cdc.gov/obesity/downloads/ bmiforpactitioners.pdf.

20. Chen J, Meng Y, Zhou J, Zhuo M, Ling F, Zhang $\mathrm{Yu}$,et al. Identifying candidate genes for type 2 diabetes mellitus and obesity through gene expression profiling in multiple tissues or cells. J Diab Res. 2013:9.

DOI: https://doi.org/10.1155/2013/970435

21. Langenberg C, Sharp SJ, Franks PW, et al. Gene-lifestyle interaction and type 2 diabetes: the EPIC interact case-cohort study. PLoS Med. 2014 May;11 (5):e1001647. 1001647

DOI: https://doi.org/10.1371/journal.pmed.

22. Liu J, Rutten-Jacobs L, Liu M, Markus HS, Traylor M. Causal impact of type 2 diabetes mellitus on cerebral small vessel disease: A mendelian randomization analysis. Stroke. 2018 Jun;49 (6): 1325-31.

DOI: https://doi.org/10.1161/STROKEAHA.117. 020536

23. Loos RJ, Hagberg JM, Pérusse L, et al. Advances in exercise, fitness, and performance genomics in 2014. Med Sci Sports Exerc. 2015 Jun;47 (6):1105-12.

https://doi.org/10.1249/MSS.0000000000000645

24. Karaderi T, Drong AW, Lindgren CM. Insights into the Genetic Susceptibility to Type 2 Diabetes from Genome-Wide Association Studies of ObesityRelated Traits. Curr Diab Rep. 2015;15 (10):83.

DOI: https://doi.org/10.1007/s11892-015-0648-8

Received 30 Nov 2020; revised 20 Dec 2020; accepted 23 Dec 2020.

This is open access article distributed under the Creative Commons Attribution License, which permits unrestricted use, distribution, and reproduction in any medium, provided the original work is properly cited. 